\title{
"ARTE DE FAZER, ARTE DE NARRAR" \\ UMA ETNOGRAFIA DE UMA PINTURA DE PAISAGEM EM PORTO ALEGRE
}

Thaís Cunegatto

Ana Luiza Carvalho da Rocha (Orientação)

O presente artigo é resultado de uma pesquisa desenvolvida no Banco de Imagens e Efeitos Visuais/UFRGS. Oriunda de meu trabalho de conclusão de curso em Ciências Sociais a proposta deste artigo está inserida numa tríade interdisciplinar que envolve as disciplinas de Antropologia, História e Artes Visuais. Numa discussão acerca das formas expressivas da vida social, encontra-se o tema da pintura de paisagem e a representação pictórica numa trama entre a cidade vivida e a cidade narrada, onde a memória é fio condutor que leva a análise deste trabalho. Objetiva-se compreender este processo de inscrição pictórica que se dá no agenciamento da memória coletiva e da memória social, onde o sujeito criador é interpelado pela cidade, neste caso, a cidade de Porto Alegre, capital do Estado do Rio Grande do Sul.

\section{Entrando em Campo}

Dias de sol ou no máximo nublado; dias de chuva, nunca. Os pingos desta afugentam as pessoas e assim o Brique adormece em alguns domingos, feito Cinderela aguardando o beijo do príncipe Sol para despertar.

Domingos chuvosos: o mês de setembro foi marcado por eles. A espera do Sol tornou-se um hábito, no sábado já olhava os céus, imaginando o dia que viria. A chuva separou por muito tempo Seu Ennio de seus clientes e, por sua vez, eu de Seu Ennio.

Mas o Sol raiou no mês de outubro e novembro, e as longas tardes de domingos tiveram a passarela do Brique estendida na rua José Bonifácio para que Porto Alegre saísse ao Parque da Redenção para tomar o seu chimarrão, sentar na grama, comprar artesanato, admirar antigüidades, ver teatros de rua e também para quem quiser ver telas de arte...

Conheci Seu Ennio em maio de 2005, com o intuito de encontrar artistas de paisagem caminhava pela cidade a procurá-los. Sabia que o Brique, constituindo-se uma feira de 
artesanato, poderia abrigar artistas com tal técnica, pois no circuito artístico, tais como exposições e na academia, sabia que não mais encontraria.

No dia 15 de maio, resolvi descer toda a Rua José Bonifácio. Caminhar desde o início da feira de antiguidades, onde as pessoas vendem livros, objetos e jóias usadas, até a feira de artesanato que desemboca na Avenida Osvaldo Aranha. Logo após passar o Monumento ao Expedicionário e as barraquinhas de comida - onde o cheiro da fritura dos pastéis e do acarajé se mistura com o cheiro da pipoca - começa o espaço das artes plásticas.

Logo na primeira banca, quadros bem abstratos, coloridos, expressão da arte contemporânea, bem como se espera encontrar; a próxima banca segue a mesma linha artística e, ao lado desta uma surpresa: entre hortênsias rosas e azuis, existem quadros de gaúchos montando a cavalo, de homens levando a boiada. Lá estão os quadros das paisagens bucólicas que me lembravam muito a pintura de regionalistas como: Pedro Weingartner ou mesmo José Lutzemberger.

Parei nesta banca, banca 38, e fiquei olhando atentamente para um grande quadro, que retratara um moinho. Perguntei à senhora ao lado quem havia pintado aqueles quadros, e ela me apontou o senhor que estava dentro de uma brasília marrom. Abaixei-me e vi que era um Senhor já com os cabelos brancos que inscreviam seus 70 anos, semblante cansado, num cochilo sossegado de quem espera o dia passar.

Seu Ennio Crusius. É este senhor com quem venho falando a cada domingo que passa, cujo Sol permite nosso encontro. Ennio Crusius é pintor de paisagem, pinta desde seus 15 anos, imerso no saber - fazer de seu pai, Oscar Crusius, também pintor de paisagem. Ennio familiarizou-se com a pintura e com os pintores que retrataram Porto Alegre. Através de suas narrativas, ele remonta a história das artes plásticas portoalegrense, nos levando para a sua meninice e para o seu aprendizado na pintura, onde encontramos os formadores do Instituto de Arte, remontando no plano de suas memórias afetivas, no plano da imaginação criadora, este circuito de trocas e aprendizagens do campo artístico.

"Quem conhece a história das Artes de Porto Alegre, conhece meu pai e todo colecionador que se preze tem uma obra dele." 
"O Ado Malagoli era amigo de meu pai, vivia lá em casa, há uns anos atrás ele foi lá em casa me visitar. Somos amigos."

"João Fahrion, o João Fahrion. Ele ia lá em casa, era muito amigo do meu pai, e daí nós pintava junto e muita coisa ele me mostrou, ele pintava mais era figura humana, ele pintava junto conosco porque ele queria pintar paisagem, meu pai pintava paisagem então ele pegou umas dicas lá, mas ele foi um gênio. João Fahrion foi um gênio, pintava muito bem."

Seu Ennio aprendeu a pintar inicialmente com seu pai, Oscar Crusius, e através dele conheceu pintores renomados tais como: Ângelo Guido, João Fahrion, Ado Malagoli. Estes pintores aparecem na fala de Seu Ennio como seus mestres e companheiros de pintura, representantes do que ele entende como arte. Nas pinceladas de Ângelo Guido e de seu pai, Oscar Crusius, Seu Ennio encontrou seu estilo artístico.

Num destes domingos ensolarados, levei comigo imagens destes pintores para que Seu Ennio as visse, pensando que talvez estas imagens pudessem evocar memórias atreladas a este saber - fazer, neste momento em que as falas acima transcritas foram relatadas. A comparação dos quadros de Ângelo Guido com os seus também foi neste momento, relembrando de seu mestre, Seu Ennio compara a paletiada do pintor com a sua paletiada, dizendo que as duas se tratam de traços impressionistas, me chamando a atenção para a leveza do traço, para o traço solto, típico impressionista.

Seu Ennio se denomina como um pintor de paisagem com traços impressionistas. Para ele, o impressionismo é transcrito na expressão "tem que dar a impressão". Os traços são leves, soltos, permitindo que a imaginação atue. Assim, relata o quadro de uma de suas alunas, que pinta com a técnica impressionista uma paisagem que retrata um mato, para dar de presente para o pai. O pai, ao receber o quadro, enxerga no mato, um urso. Este urso é o impressionismo, um urso que não foi pintado, mas aos olhos deste senhor, estava lá. O impressionismo para o Seu Ennio é este urso.

A trajetória social de Seu Ennio é significativa das tensões que permeiam a pintura de paisagem no campo das artes plásticas hoje, em Porto Alegre. Tendo aprendido inicialmente com seu pai, Oscar Crusius, um importante artista plástico local, renomado 
pintor de paisagem, tendo aprimorado a técnica desta pintura no Instituto de Belas Artes, como aluno de Ângelo Guido.

A obra de Oscar Crusius retrata não cenas urbanas, mas paisagens rurais, ditas e vistas como "típicas" do Rio Grande do Sul. Em seu Dicionário das Artes Plásticas no Brasil, Roberto Pontual ${ }^{1}$ cita-o como pintor de "aspectos da paisagem e dos costumes regionais gaúchos".

Para Seu Ennio, seu pai lhe é motivo de orgulho, e isto, transparece quando narra a sua trajetória de artista, constantemente acompanhada da expressão: "meu pai foi um grande pintor!”, ou da frase: “colecionador que se preze tem um quadro de Oscar Crusius!”. Em sua pintura de paisagem, Seu Ennio menciona a influência da obra de seu pai, que morreu em 1991, com 88 anos.

Como seu pai, Seu Ennio teve sua formação no Instituto de Belas Artes, e tal como ele, aprendeu a pintar com Ângelo Guido "suas pinceladas impressionistas". Nos livros do pai, Seu Ennio estudou anatomia dos cavalos, figura que se encontra quase sempre presente na sua forma de retratar a paisagem urbana porto-alegrense.

Ennio perpetua assim o estilo de seu pai e as pinceladas de seu mestre, Ângelo Guido, sendo herdeiro desta tradição figurativa de pintura de paisagem, denota em sua pintura a relação emocional que existe entre o indivíduo e o objeto fabricado, entre Seu Ennio e sua arte, mostrando a existência da resistência à mudança do traço, do estilo, resistência esta que Franz Boas (2003), no estudo da arte primitiva, apontava como forma de expressão de sentimento que se filiam certas formas e a valores sociais ou religiosos que impedem a mudança, pois o "próprio domínio da técnica, a força dos hábitos motores e as associações entre as formas e as imagens visuais evocadas contribuem a fixar a formas antigas, tornando difícil a inovação” (BOAS, 2003:179).

\section{O Brique da Redenção}

Ainda que não mais ocupando um lugar nobre no interior do campo das artes plásticas local e regional, a pintura de paisagem ainda se faz presente, não mais nos museus e galerias de artes plásticas, mas nos espaços públicos das feiras e dos mercados das pulgas,

${ }^{1}$ Este comentário foi extraído do site http://www.casaartecanoas.com.br/b_crusius.php, encontrado no sistema de busca do Google ao pesquisar o nome de Oscar Crusius no dia 14/09/2005. 
entre elas, o Brique da Redenção. Situado no Parque Farroupilha, antigo Campos da Várzea, o Brique da Redenção consiste numa feira de artesanato, de antiguidades, de artes plásticas e de alimentos que ocorre todos domingos há mais 23 anos.

A disposição espacial do Brique da Redenção está dividida em setores que se apresentam por toda a extensão da rua José Bonifácio e que vai da avenida Osvaldo Aranha até a avenida João Pessoa. Para quem vem desta última avenida, a feira de antiguidades (ou mercado das pulgas) é o que logo se apresenta para o visitante, seguida do setor de alimentação (em frente ao Monumento ao Expedicionário, situado em uma das pontas do eixo central deste Parque). Ao lado deste setor encontra-se o setor de artes plásticas, e, na sequiência, o do artesanato que tem como ponto culminante o comércio do artesanato indígena, já próximo à avenida Osvaldo Aranha.

"É o brique, deixa eu vê, 81, talvez 80. Naquele tempo era o Mercado das Pulgas, chamava, depois virou Brique. Quando eu vim pra cá falavam Mercado das pulga, mas já tava virando brique, isso foi 82,83 , junho de 83 eu vim pra cá. Naquele tempo se vendia bem, né. Agora não se vende mais nada. Começou, só com antiguidades, depois começou com os quadros e artesanato tudo misturado, depois separaram Artes Plásticas, Artesanato e Antiguidades, separam tudo.”

Esta setorização é evidente dentre aqueles que possuem banca no Brique da Redenção. Seu Ennio comenta estas delimitações espaciais que cercam o local para uma senhora que pede informações sobre artigos em couro: "A senhora está no setor de artes plásticas, vá mais adiante que encontrará o artesanato”. Observa-se a presença da separação entre artista e artesão, já trabalhada por Pierre Bourdieu (1996), na sua obra As regras da Arte. Segundo este autor nos mostra, trata-se de uma disputa pelo campo de conhecimento, onde o artista plástico repudia o estatuto de artesão, pois este não compartilha o ethos e o habitus do campo artístico.

Neste jogo entre artista e artesão, Seu Ennio ressalta as críticas que teve ao expor seus quadros no Brique da Redenção, pois pintores que lá expunham se caracterizavam como pintores de terceira, pintores que não tinham erudição, pintores que não se integram ao campo artístico. Diante disso, Seu Ennio demonstra que deve ter todo o cuidado na fabricação de uma obra, pois seus críticos sempre o estarão julgando. 
Numa tentativa de mostrar seu talento e despistar estas críticas que o aproximariam de um artesão, Seu Ennio relata a dificuldade em conseguir uma vaga no Brique da Redenção.

\begin{abstract}
"Tudo é bem organizado, tem conselho, tem triagem, quando desocupa um box, tem triagem, tem que fazer exame, exame, tem que tá na presença do examinador, depois é dado nota. Pra pegar as vagas. Quando eu vim pra cá tinha 80 candidatos 4 vagas e eu peguei uma das 4 vagas.Pintor eu fui o único, depois teve uma ceramista, depois passou a fazer aquarela, mas fazia cerâmica naquela época que entrou como ceramista, teve um com negócio de tapeçaria e um com negócio de fotografia artística, não si o que, foi os quatro. E pintor só eu e a nota mais alta. (...) tem reunião, no lugar que eles marcam, é na Smic, mesmo, antes era Carlos Gomes, agora parece que é na Andradas. Marcam uma reunião com o pessoal e os candidatos se apresentam num determinado local, que tenha espaço pra trabalhar e que todo mundo vai olhar o que o cara tá fazendo, depois era dada as notas, antigamente não precisava fazer o trabalho na presença do examinador. Eu por exemplo não precisei fazer, apresentei quatro trabalhos meu e fui aprovado, depois mudaram ."
\end{abstract}

Seu Ennio alerta que ser um pintor do Brique, para alguns, destitui o artista de seu prestígio enquanto tal. Porém, para ele, a perpetuação desta valorização enquanto artista fica numa trama entre o dinheiro e o prestígio. Para os pintores que o consideram de terceira linha, Seu Ennio retruca com o fato de que estes pintores estão encapsulados, destinados ao fracasso, pois a arte destes não é mais exposta, é uma arte sem público. Estes pintores o julgam por tornar a arte mais vendável, mas estes mesmos, segundo ele, não ganham nada mais com a arte que fazem, pois embora o Brique seja uma feira de artesanato que desmereça um trabalho artístico, nos dias de hoje é o único espaço reservado para o comércio desta arte figurativa de pintura de paisagem.

Esta tensão na comercialização da arte nos é apontada por Roger Bastide (1971), em seu livro Arte e Sociedade, em que o autor discute o processo de endeusamento dos pintores e artistas em geral e a posterior demonização dos mesmos ou dessacralização, quando estes devem vender-se ao circuito comercial, pois embora sejam endeusados, não são deuses e como mortais, precisam alimentar-se, vestir-se e para tal, necessitam do comércio de suas obras.

No que tange à comercialização de suas obras, Seu Ennio reclama da pouca valorização de sua arte, não só por parte de seus pares, como relatado acima, mas também por parte da sociedade, das pessoas que circulam no Brique que não se dão conta de que 
suas obras estão quase apreço de custo, sentindo assim, seu trabalho desvalorizado. No momento da venda, a performance é sempre a mesma, a fala repete-se para todos os clientes:

"Este quadro aqui nas minhas exposições é $\mathrm{R} \$ 350$, mas aqui eu vendo por $\mathrm{R} \$ 140$, mas se for avista dá pra fazer por $\mathrm{R} \$ 100$. Os pequeninhos, estes na minha exposição eu vendo por $\mathrm{R} \$ 70$, aqui eu vendo a $\mathrm{R} \$ 15$, dois por $\mathrm{R} \$ 25$.”

A desvalorização de seu trabalho não se vê apenas nestes momentos de barganha, mas também no momento da escolha do quadro. Seu Ennio confessa que seus clientes nunca escolhem seus melhores quadros. A beleza encontrada por seus clientes está dissociada do bom exercício da técnica. O sentimento do belo, segundo ele, não está atrelado, no caso deste público, a nenhuma espécie de erudição artística. Para ele seus quadros mais belos são os mais bem trabalhados, os que impressionam através do impressionismo, mas estes são os permanecem em sua banca.

A venda, para ele, é uma simples troca. Entretanto, uma troca em que o artista sempre perde, não apenas financeiramente, como também espiritualmente. Seu Ennio acredita que os quadros carregam a energia de quem os pinta:

"Quando estou junto aos quadros do meu pai, eu sinto o meu pai. Acredito que se tu colocar as mãos sobre a tela de um pintor tu vai sentir esse pintor."

A energia que está intrínseca no quadro seria o que Marcel Mauss (2003) denominou de mana, neste caso, o mana do quadro. A idéia de mana, de algo nosso que o objeto possui, foi relatado pelo pintor quando ele me presenteou com um de seus quadros, como forma de agradecimento de compartilhar com ele todas as tardes de domingo e ouvir um velho, coisa que ninguém mais faz nos dias de hoje.

Seguindo na linha de Marcel Mauss (2003), sentia-me em dom com Seu Ennio, queria dar-lhe algo também feito por mim. A idéia do vídeo, de uma filmagem dele enquanto pintava já havia sido pensada e sugerida por minha orientadora. Foi então, que lancei a idéia da filmagem como uma forma reciprocidade, uma retribuição ao quadro dado, daria a ele um pequeno trecho editado em seu momento de criação. 


\section{Do arrabalde ao centro e do centro ao arrabalde: itinerários que conformam o olhar} plástico.

As moradas de Seu Ennio sempre foram descritas como espaços calmos, acolhedores, lugares tidos como fontes de inspiração. Uma lembrança feliz ecoa ao narrar os bairros pelos quais passou.

Nasceu no Bairro Floresta, na rua Comendador Azevedo, na casa que era de sua avó e o espaço de sua infância em que viu através das janelas do sótão a cidade de Porto Alegre alagada após a enchente de 1941 :

Os cabelos brancos e voz roca criam a imagem de um idoso que se contrasta com o vigor da infância que salta no brilho dos olhos ao narrar as proesas de seu tempo:

\footnotetext{
"Quando eu era criança e água ia até o sótão, nós morava no sótão porque em baixo não dava, a água passou da janela, muito por cima da janela, metade da janela assim e na escada nós amarrava um barquinho que nós tinha. Choveu muito, muito vento Sul, Vento Sul represou o rio, Vento Sul represou o rio. Choveu, muito, muito, muito mesmo e o vento era Sul, o vento batia assim... e o rio represou e foi pra dentro da cidade e inundou tudo. Incrível."
}

Suas lembranças individuais, memórias subjetivas entrecruzadas com a memória da cidade, permitem que ouvinte seja levado ao espaço narrado e a poesia da narrativa interpele, tanto o narrador quanto o ouvinte. A pintura é feita também no jogo destas memórias, o que permite a nós, espectadores, nos lançarmos e aderirmos a esta como parte constituinte de nós mesmos.

O itinerário urbano de Seu Ennio nos revela um intenso deslocamento por Porto Alegre, e com um isso uma aprendizagem de várias feições da cidade, do arrabalde ao centro, do rural ao urbano.

“Comecei a morar no Menino Deus em 46, depois em 75 eu saí do Menino Deus. Não, em 55 eu saí do Menino Deus e fui morar na Rua Leão XIII, ali na Cidade Baixa, depois sai da Leão XIII e fui morar num apartamento, ali que meu pai comprou, na XVII de Julho, a rua dos Coqueiro, daí eu fiquei até 75. Não, 75 eu fui pra lá, fiquei até 91, quando meu pai morreu. Quando meu pai faleceu eu fui pra casa do meu pai , pra minha mãe não ficar sozinha e emprestei o apartamento pr'um outro filho meu e aí voltei pro Menino Deus. Daí minha mãe faleceu, e eu fiquei no Menino Deus até 1999, quando eu, 1998, quando eu fui pra Guaíba, fiquei até fim de 1999, princípio de 2002 eu vim aqui pro morro Santa Teresa." 
O deslocamento pela cidade não deu-se apenas através do caminhar e do morada, mas também através da pespectivadas das águas, onde relatos de passeios a barco com o seu avô pela orla do Guaíba emergem numa narrativa das ilhotas do rio Jacuí. Seu Ennio contempla assim cidade vista do Guaíba, cidade esta que conforma o olhar, um olhar atravessado também pelos longos 37 anos em que trabalhou na Mercantil Arroz e que grandes plantações faziam parte de seu cotidiano:

“...é considerado parque estadual, tudo, aquelas ilha ali, tá tudo tombado, ali no Delta do Jacuí, Ilha Grande dos Marinheiros, Ilha da Pintada, aquilo tudo é considerado parque. Aquilo nós conhecia que nem a palma da mão andava de barco por tudo aquilo."

Sobre a Mercantil Arroz, Seu Ennio relata:

"Nós carregava nosso arroz pra Rio Grande com as nossas próprias chapas e tinha um engenho grande lá Tapes, trabalhava com engenho lá no Uruguai, um uruguaiano recebia arroz lá, eu trabalhava com crina vegetal, eu cuidava dos crinero que tirava do butia, aquela crina antiga, umas folhas faziam o chá, nós tudo fazia. Trabalhei feito um animal e não ganhei nada, no fim eu só queria pintar, sair, e daí depois a minha vida ficou difícil, porque a pintura é difícil, né".

Os lugares de passagem de Seu Ennio e as memórias dos lugares vividos se misturam com o legado paterno, configurando sua arte numa mesma ambiência daquela remetida pelo pai: paisagens rurais, feitio arrabalde. As imagens pintadas por Seu Ennio retratam lugares de sua memória: imagens de uma paisagem porto-alegrense de outra época, mesclando a ambiência urbana e a atmosfera bucólica da vida rural de seus arrabaldes. Seus quadros de Porto Alegre insistem em fabricar sua feição de origem rural, onde se pode ser um gaúcho que anda a cavalo no bairro da Glória que, segundo ele, "não tem apenas antenas de TV". Esta feição contemporânea da cidade Seu Ennio recusa-se a pintar: "se tiver que pô-las, prefiro não pintar o bairro". Ao falar sobre os cavalinhos, "os cavalinhos sempre estão lá... (fala apontando para os quadros) embora não estejam”.

Na indagação sobre o processo da construção plástica de Porto Alegre, da impressão de uma Porto Alegre em suas telas, Seu Ennio revela a importância da memória ao afirmar: "pinto de memória, pinto paisagens de infância, de quando era criança ou mesmo já adulto, mas que não vivo mais". Para seu Ennio, pintar a paisagem de Porto Alegre é lembrar dos 
detalhes vividos em alguns de seus lugares na busca de retratá-los com perfeição. É partir de suas lembranças e convocar sua imaginação criadora de artista para transladar a alma destes lugares para a tela.

Esta relação do pintor e de sua obra em face da cidade moderna pode ser interpretada à luz dos comentários de Franz Boas (2003) sobre os fatores que podem levar a arte à mudança em seus estilos: se a cidade se transforma, sua arte se transforma. Sendo assim a cidade moderna torna-se o palco de transformações do próprio fazer artístico. Entretanto, as transformações da cidade são vividas, mas não retratadas nas obras de Seu Ennio. Michel De Certeau (1997), ao mostrar que as transformações vividas pelos habitantes das grandes cidades são negociadas e agenciadas por eles em suas lutas cotidianas pela manutenção de suas tradições, na transmissão de um saber-fazer e ao mesmo tempo na implementação do novo, podem ajudar na compreensão do processo de perpetuação de um estilo artístico como o de pintura de paisagem, realizada hoje em Porto Alegre, frente às outras formas de expressões artísticas de vanguarda.

\section{Retomando a Morada: Entrando no Espaço Doméstico}

"Os verdadeiros bem-estares têm um passado. Todo um passado vem viver pelo sonho, numa casa nova"

(BACHELARD, 2003:25)

A proposta da filmagem me propiciou adentrar, como diria Bachelard (2003), no canto do mundo de Seu Ennio: em sua morada, em sua casa, conhecer sua esposa. Enfim, entrar em sua esfera doméstica.

Espero o telefone tocar, ele chama na casa. Do outro lado, ouço uma voz grave de mulher. Beatriz, a esposa de Seu Ennio atende. Eu havia ligado para marcar o horário de minha visita. Beatriz me atende muito atenciosa, mostro a vontade de conhecê-la e ela responde de forma recíproca, dizendo que Seu Ennio fala muito sobre mim e que me conhecer. Seu Ennio, não estava havia ido buscar as netas no Prelúdio² , liguei mais tarde e marcamos no sábado dia 04/11 às $14 \mathrm{~h}$.

\footnotetext{
2 O Prelúdio é uma escola de música que funciona como um Projeto de Extensão da Universidade Federal do
} Rio Grande do Sul (PROEXT/UFRGS). 
No sábado, pego o ônibus $T V$ e desço na esquina da rua Cleveland, onde posso ter uma vista panorâmica da cidade do topo do Morro Santa Teresa. Na esquina da rua de Seu Ennio, tem uma linda árvore com flores rosas, um pouco abrochadas tampando o asfalto. Sigo em frente, crianças jogando bola. Chego na casa. Não há campainha. Ligo para visar a minha chegada, mas já de fora consigo ver uma linda casa de madeira com dois pisos. Beatriz atende e me avisa que Seu Ennio vem abrir. O portão se abre, Seu Ennio me apresenta aos cachorros que, brabos, anunciam aos outros minha chegada.

No terreno estão três casas: as duas da frente de seus filhos e a do fundo dele e de Beatriz. As casas são muito parecidas: mesmas madeiras e dois pisos. Chegando perto da casa de Seu Ennio, um chafariz transbordando uma espuma branca de bolas de sabão, na entrada da casa uma placa de madeira anuncia: ENNIO CRUSIUS.

Entrando na casa, encontro com Beatriz. Uma linda mulher, com sua linda voz de contra-alto, já exibida no coral da Ospa. Beatriz me abraça e, junto com Seu Ennio me mostra sua morada.

Em suas madeiras escuras, a casa se escurece, a luz fica apagada, o rádio o tempo inteiro ligado em alguma estação onde o Roberto Carlos toca o tempo todo, nas paredes quadros e mais quadros.

Quadros do pai e quadros dele se misturam nas paredes, os quadros não estão necessariamente na altura dos olhos: estão em cima, mais abaixo, na altura da cintura, embaixo da escada, em cima dos sofás, por todas as paredes. Seu pai está em todas elas, seja através de sua pintura, ou mesmo no retrato feito por Ângelo Guido.

Na mesinha de canto, perto da escada, estão os artesanatos feitos por seus colegas do Brique. A cozinha fica na mesma peça em que a sala, separada por um balcão, que nos aguarda com um café, que será servido em xícaras de porcelana, apenas para mim e para Seu Ennio, pois Beatriz toma-o em um copo. As louças da família são guardadas, os talheres de prata estão cuidadosamente guardados dentro de uma gaveta nesta mesinha perto da escada.

Subindo as escadas, temos à direita o banheiro. À esquerda, o quarto do casal e em frente, $\mathrm{o}$ atelier. $\mathrm{O}$ atelier é peça mais clara da casa, com duas grandes janelas, que mostram os lindos contornos do Morro Santa Tereza e do Morro da Glória. O reflexo da luz incide 
numa pequena mesa onde estão dispostos bastões de tinta acrílica, de todas as cores: verde, azul cobalto, magenta, marrom, branco, violeta e várias outras. Ao lado, um vidro repleto de pincéis de espessuras e tamanhos variados. Ao lado da mesa, uma cadeira com almofada disposta à frente do cavalete, que abriga um quadro pronto que repousa para secar.

$\mathrm{Na}$ parede à direita de quem entra no atelier, há uma estante, que guarda todos seus quadros e os quadros do pai, numa mescla de paisagens que exercitam o olhar a distinguir a autoria do quadro focado. Nesta mesma estante, encontram-se objetos dos mais variados: ferros de passar, vasos. Todos aqueles objetos dos quais citei existir no Atelier Livre da prefeitura também se encontravam do atelier de Seu Ennio. No lado esquerdo da sala, próximo a uma das janelas, encontra-se um pequeno sofá e uma mesinha de centro, criando uma pequena sala dentro do atelier. Ao lado do sofá, outra estante: nesta se encontram os esboços, ensaios, testes e estudos de Seu Ennio e de seu pai.

Entre os esboços e os projetos de estudos, se encontram as fotos de família, que são exibidas com orgulho por Seu Ennio, onde ele me mostra sua esposa no palco da Ospa, vestida elegantemente para uma Ópera, da qual ela havia participado. Todas as fotos compunham uma espécie de álbum profissional e ao mesmo tempo familiar, no que tange o casal, pois eram cenas de exposições ou de Óperas, das quais ambos apreciam o trabalho do parceiro.
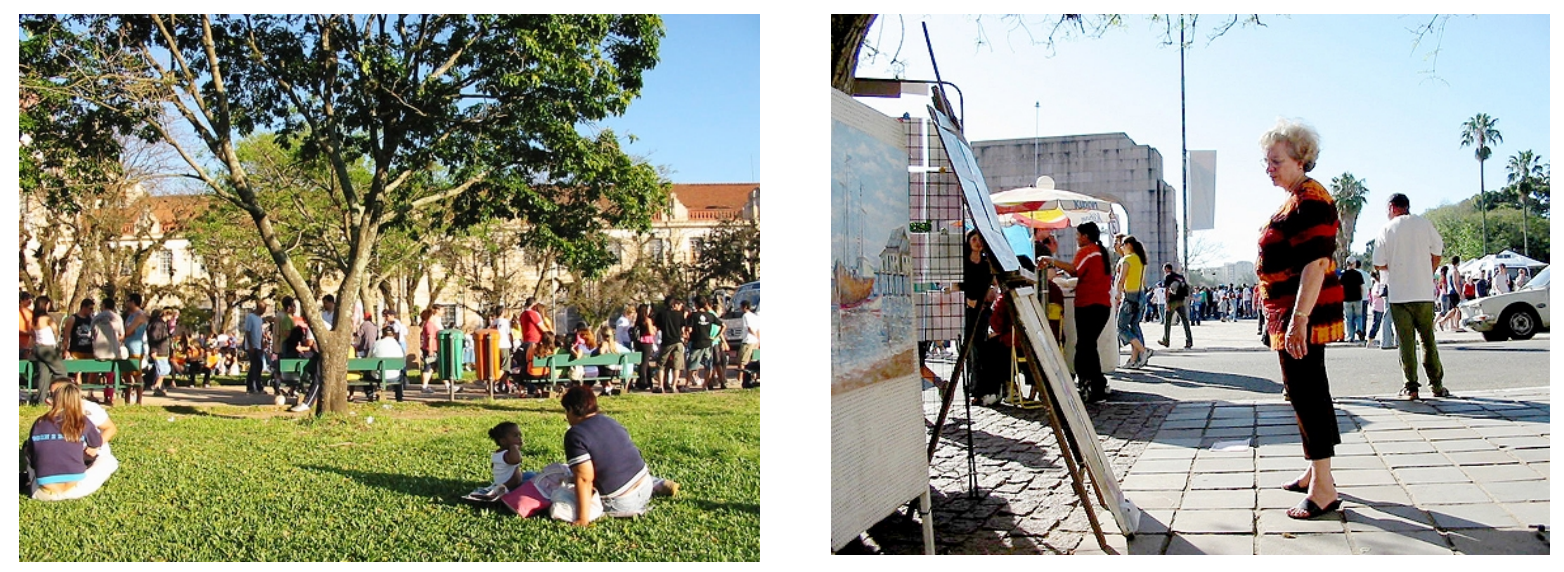

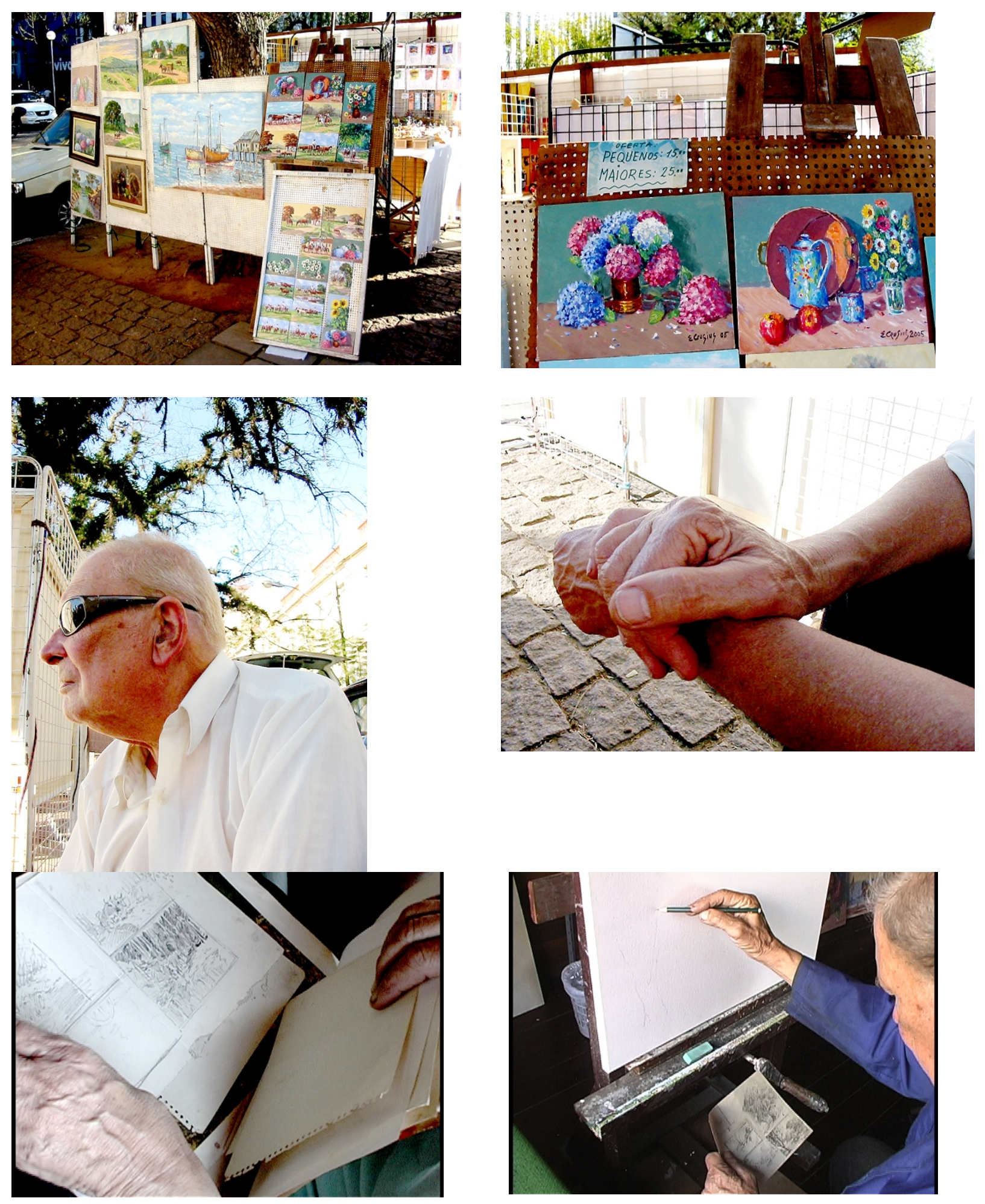

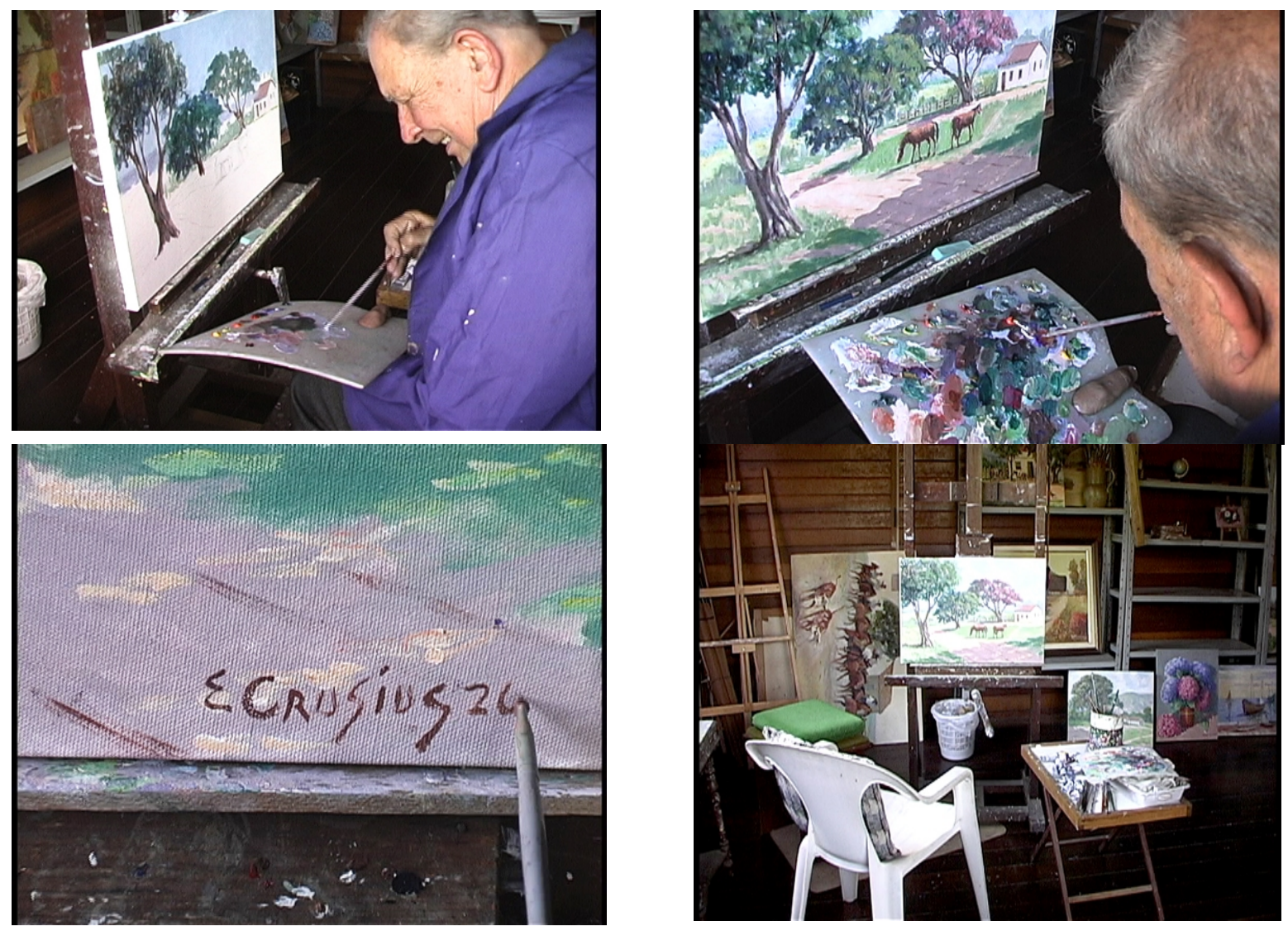

\section{O jogo Performático: Entre o Pincel e a Câmera}

Saí da casa de Seu Ennio, no dia 04/11/2005, tendo marcado a gravação para a próxima semana, no mesmo horário. A filmagem, então, estava marcada: sábado, dia $11 / 11 / 2005$, às $14 h$. Durante a semana, os preparativos foram feitos: a compra da tela na qual Seu Ennio nos faria uma paisagem, a elaboração do roteiro de gravação, a entrega dele à minha orientadora, as correções feitas, e o repasse para a Equipe de Filmagem: Rafael Devos e Anelise Guterres, ambos pesquisadores do Banco de Imagens e Efeitos Visuais, grupo de pesquisa onde atuo como bolsista de Iniciação Científica.

Rafael e Anelise revezariam a câmera, cuidariam da captação do som, enquanto eu faria as provocações que guiariam nosso encontro. Tudo acertado. A rua Botafogo foi nosso ponto de encontro. De lá, sairíamos até a casa de Seu Ennio.

Na hora e lugar marcado, estávamos lá. Ao chegarmos, Seu Ennio estava no portão, onde nos recebeu alegremente. Fui saindo na frente para apresentar a equipe. Enquanto a 
Anelise ligava a câmera, eu apresentava o Rafael. Fomos entrando na casa, guiados por Seu Ennio, que mostrava para os meus colegas e para câmera sua bela morada.

Uma conversa curta acerca da casa e nos dirigimos ao atelier onde seriam filmados Seu Ennio pintando, e eu, etnografando. Dois jogos de cenas numa mesma cena. Duas performances num mesmo palco. O olho da câmera, guiado pelos olhos de Rafael e Anelise faria o papel da platéia, e é para a câmera que as cenas são dirigidas.

Seu Ennio abre o invólucro da tela, já estranhando o tamanho dela, pequenas reclamações começam a serem feitas: a espessura e o tamanho não condiziam com o esperado pelo pintor, que coloca a tela no cavalete e começa a se "montar" enquanto tal, vestindo-se com um jaleco azul que impede que as tintas manchem sua roupa.

O próximo passo foi à escolha do desenho; um desenho que se ajustasse ao tamanho da tela, uma paisagem mais horizontal. Nos seus rascunhos e nos de seu pai, Seu Ennio busca o desenho a ser pintado: observa as proporções, contabiliza os espaços, num dialogo em voz baixa consigo mesmo. O desenho foi escolhido: uma paisagem de arrabalde. Uma casinha cortada por uma estrada de chão batido com uma paineira ao lado.

O desenho passa então aos domínios da tela. Com um lápis 2B, Seu Ennio o transcreve para ela, o mais absoluto silêncio predomina no ambiente, escuta-se apenas os riscos do lápis sobre a tela. A imagem começa a se formar, criando uma outra composição, diferente daquela esboçada no papel. Numa junção dos elementos propostos por seu pai e dos elementos compostos por ele, surge a paisagem a ser pintada. A mesma casinha de madeira, com mesma estrada, porém nesta estrada estão lá os cavalinhos.

Seu Ennio coloca em sua paleta todas as tintas. Pequenos pingos são dispostos nela. Sentado à frente do quadro, segurando a paleta com o polegar esquerdo, o pintor me remetia a imagens de pintores clássicos. Sua posição ereta na cadeira, seu olhar fixado na tela faziam menção a uma forma tradicional de pintar um quadro. O pintor começa a nos relatar a sua técnica impressionista, alternado entre nossas conversas e seus ensinamentos, momentos do mais absoluto silêncio.

Durante todo o processo de pintura, Seu Ennio permaneceu sentado, ora aproximando-se, ora afastando-se da tela. Estes deslocamentos do corpo na cadeira indicavam a própria técnica utilizada. Na fusão dos relatos, tanto de Seu Ennio, quanto da 
professora do Atelier, o Impressionismo é uma técnica que utiliza pinceladas soltas que vistas de perto são meros pontos na tela. No distanciamento, a imagem se forma. $\mathrm{Na}$ proximidade entre os pontos, se faz a paisagem.

$\mathrm{O}$ ir e vir, a inquietude de um olhar que busca a cor certa e o ponto exato se transpunha na expressão do pintor que, compenetrado, silenciava muitas de minha provocações. Seu Ennio mantinha seu personagem de pintor recompondo sua trajetória, não só nos seus gestos, mas também em sua narrativa. Remontava seus mestres e seu percurso enquanto pintor. Adentrava em suas narrativas biográficas, sem perder de vista a câmera que o filmava e seu papel enquanto pintor e mestre. Não éramos apenas o seu público, mas também seus alunos.

Analiso aqui a cena de gravação como um jogo performático. Tanto meu desempenho enquanto etnógrafa, quanto o desempenho de seu Ennio como pintor estavam sendo registrados.

Segundo Finnegan (1992), a performance é um jogo de interação entre o artista e o expectador, onde o modo de usar a linguagem, a entonação, o ritmo, a retórica e a dramatização, são elementos cruciais na análise. Seu Ennio performatizava assim, seu trabalho enquanto artista, através de sua oratória, que busca em seus mestres a tradição do ato da pintura de paisagem. Sua fala é calma, acompanhando seus gestos lentos, sem contrapor os momentos de silêncio, que permitem que o barulho do pincel se sobressaia na tela. Seus movimentos lentos do corpo se contrapunham a rapidez da mão, no momento da impressão da tinta na tela.

A gravação compunha então um momento extraordinário, fora da ordem cotidiana, não rotineira, fazendo o pintor ressaltar seu papel enquanto artista plástico. O fato de pequenas historietas serem elaboradas a partir da gravação e colocadas na Internet, através do site do Banco de Imagens e Efeitos Visuais, gerava um outro público e um espectador que não se restringia apenas às pessoas que ali estavam. O seu trabalho devia ser mostrado e provado, gerando assim, uma ênfase na figura do pintor e a todas as histórias e expressões corporais que o constituíam enquanto tal.

\section{"A arte está no sangue!"}


Na busca da compreensão da narrativa biográfica de Seu Ennio Crusius e imersa nos relatos dele acerca de suas relações familiares, de sua parentela, como contraponto de uma fala possivelmente egóica, demonstrarei uma fusão de vários relatos e entrevistas feitas onde contradições são expostas, constituindo assim, a trama e o drama da vida social em seu contexto familiar.

Utilizarei aqui os três níveis propostos por Edmund Leach (2001), no livro Repensando Antropologia. Anunciando assim, esta descrição numa alternância da voz passiva e a voz ativa, onde a articulação textual construi-se no diálogo entre as falas e reflexões de Seu Ennio com minhas reflexões e constatações.

Seu Ennio Crusius, sendo pintor de paisagem desde seus 15 anos, imerso no saberfazer de seu pai, Oscar Crusius, também pintor de paisagem, familiarizou-se com a pintura e com os pintores que retrataram Porto Alegre através da arte de seu pai.

Para Seu Ennio, como já dito, seu pai lhe é motivo de orgulho. Em sua pintura de paisagem, Seu Ennio sempre menciona a influência da obra do pai. Como seu pai, seu tataravô também era vinculado à arte. Era um violinista que veio da Alemanha, chamava-se David Crusius, era professor de violino, dava aula a uma moça que se chamava inicialmente Carmem, mas depois se lembra que o nome da moça era Carolina. David se apaixonara pela aluna e aluna pelo professor. Carolina teve que vir para o Brasil porque seu pai, vendedor de jóias semi-preciosas, ficara sabendo que em Taquari havia estas pedras. No dia do embarque, David foi falar com o capitão do navio para ver se ele conseguia um lugar a bordo. Contou sua história de amor e explicitou que não poderia ficar longe de sua amada. O capitão, assim, conseguiu um lugar, colocando-o como agregado da família. Esta narrativa desencadeia a explicação do nome de sua neta, que se chama Carolina, em homenagem a sua tataravó.

"Ele veio pelo Frederick Henicking, o navio alemão. Ele veio até Rio de Janeiro. Do Rio até Rio Grande, durante a viagem morreram três ou quatro, que simplesmente atiraram no mar. O capitão comprou menos comida do que era pra comprar e o pessoal ficou sem comida, ficaram fraco, uns morreram quase que de fome, até criança morreu. Foi uma viagem terrível. Depois, de Rio Grande eles foram pra São Leopoldo, vieram a Porto Alegre, depois foram à São Leopoldo.” 
Seu Ennio conta que sabe da história de seu tataravô através da narrativa, das histórias de família re-contadas por sua avó que lia e relia os diários de viajem do avô David.

Seu Ennio diz que seu tataravô, além de violinista era marceneiro, ofício que seu avô paterno herdou. Por sinal, suas netas Jaqueline e Ju são exímias violinistas. Estudam no Prelúdio e quando elas tocam nas apresentações, são sempre as últimas por sua magnitude.

Todos estes relatos familiares e estas correlações feitas entre o avô e o tataravô, do próprio tataravô com as netas, e do pai com ele mesmo, são elaboradas numa tentativa de explicar os elos dos saber-fazer com o sangue.

A arte sendo transmitida através do sangue, das relações de parentela paterna e exaltação desta parte da família, demonstra o plano ideal, ou seja, o terceiro plano indicado por Leach (2001). O ideal de família atrelado a um ofício, a um saber-fazer, como diria De Certau (1997). No plano ideal, sua família tem a marca do saber artístico.

Seu Ennio casou-se com Beatriz, uma cantora da Ospa, intensificando assim a probabilidade da transmissão da arte aos seus filhos. Parafraseando Lévi-Staruss (1982): “embora o casamento dê origem a uma família, são as famílias que dão origem ao casamento". Podemos fazer um trocadilho para este caso específico: "embora o casamento dê origem a uma família artística, são as famílias que dão origem ao casamento com a arte".

Obviamente o saber-fazer do campo artístico é transmitido através de códigos culturais engendrados no seio da família, fazendo-se, com regra, a inserção de seus filhos e do filho de seus filhos na linguagem artística e no campo artístico propriamente dito. O tataravô de Seu Ennio transmitiu ao seu avô as regras do ofício de marceneiro através da lida cotidiana. Tal como seu pai, Oscar Crusius transmitiu a ele o ofício de pintor, instigando o filho e explicitando as regras da arte. Porém, o ofício não é apenas transmitido através da observação dos gestos de sua parentela. É também buscado através de instituições de ensino, tal como o Prelúdio para netas, que tocam como o tataravô.

Esta transmissão se faz através de regras, através de educação que prepara a família numa inserção aos códigos e regras da arte. Estas regras e este saber-fazer, transmitidos através de gerações, correspondem ao segundo nível proposto por Leach (2001) que estão intimamente vinculados aos padrões de comportamento e traz os ideais e os valores 
fundamentais que regem o seio familiar, neste caso, a transmissão da arte, indicada anteriormente no plano ideal.

O comportamento real dos indivíduos encontra-se, no entanto, na vida cotidiana, não apenas através da narrativa, porém numa junção da observação com os relatos, extraímos com diria Raymond Firth (1998), "fatias de vida". No momento em que Seu Ennio faz a relação do nome de sua tataravó, que inicialmente era Carmem, e após transformou-se em Carolina, explicando a origem do nome de sua neta Carolina, notamos que a narrativa é construída e reconstruída através do plano ideal. Porém, o plano real demonstra outras nuances. Vemos que o lado materno da família de Seu Ennio não é relatado, excluindo a transmissão deste lado da parentela e praticamente o excluindo de seu mapa de parentesco.

Na relação com seus filhos, observo que estes nunca são narrados, embora morem no mesmo pátio que o pai. Numa de minhas visitas à casa da família, percebo que nenhum deles interessa-se por nenhuma forma de expressão artística, o faz que Seu Ennio retire-os de sua narrativa enquanto pintor.

Compreendo aqui que os três planos propostos por Leach (2001) estão intimamente ligados e na junção destes, através da observação participante e de entrevistas, podemos extrair parcelas destas "fatias de vida" para compreender um pouco mais as relações familiares que constituem a vida do meu informante.

\section{Entre ressonâncias e repercussões}

Para Gaston Bachelard (2003), a recepção da obra de arte se dá num movimento intenso entre ressonâncias e repercussões. As ressonâncias dispersam-se nos diferentes planos da nossa vida no mundo; a repercussão nos convida a um aprofundamento na nossa própria existência. No caso da pintura de paisagem, a ressonância estaria na fabricação da obra, para o pintor ou num passar de olhos, para o receptor. Enquanto a repercussão estaria na adesão à obra, na imersão na imagem que ela evoca. A repercussão opera uma inversão do ser, fazendo parecer que o ser do pintor é o nosso ser.

A adesão a estas imagens é um fluxo entre ressonâncias e repercussões. Tanto o pintor, que adere a imagens já pintadas e faz destas suas imagens, quanto o não-pintor, que transforma as imagens por outrem pintadas em imagens lhe lhes dizem respeito, tornado-se 
assim, uma espécie de pintor, alimentando no desejo à obra uma espécie de desejo de ter criado a obra, numa sensação de adesão tal que vê nele a potência da criação desta que no plano da imaginação criadora, já lhe pertence.

Para Bachelard (2003), na linha da fenomenologia da imaginação, é necessário habitar as imagens na região passional para compreendê-las, para estudar as imagens poéticas em sua realidade superior. O autor num diálogo com Jean Lescure, coloca a voz de Lapicque:

\begin{abstract}
"Se, por exemplo, pinto a passagem do rio em Auteuil, espero que minha pintura me traga tanto imprevisto, embora de outro gênero, quanto o que me trouxe o curso d'água verdadeiro que vi. Nem por um instante se trata de refazer exatamente um espetáculo que já pertence ao passado. Mas necessito revivê-lo inteiramente, de uma maneira nova e pictórica desta vez, e, assim fazendo, dar a mim mesmo a possibilidade de um novo choque". (BACHELARD, 2003:17)
\end{abstract}

Lescure, então, conclui: "O artista não cria como vive, mas vive como cria".

O pintor não recria seu passado nem o passado da cidade ao representá-la, mas se embebe de ambos no momento da representação; precisa da sensação de uma árvore, do cheiro, do conhecimento de sua concretude, da recordação das folhas em dias de outono ou primavera, para recriá-la pictoricamente. Para pintar uma casa, é necessário habitá-la no plano da imaginação para dar a ela o aconchego que uma casa possui. Neste sentido, encontra-se a expressão "pintar de memória", usada por Seu Ennio. Neste translado de suas memórias afetivas de infância, dos espaços habitados na cidade vivida, da cidade narrada pelos seus avós, e da cidade representada por seus mestres para representação pictórica destas, obtém-se uma mescla do vivido, do narrado e do representado nos enquadres de suas telas.

Para este pintor, o translado se dá em sua técnica impressionista, que lhe permite uma melhor negociação entre o real e pictórico, pois possibilita que a imaginação atue na leveza dos traços, pois a imaginação, como diria Bachelard "desprende-nos ao mesmo tempo da realidade e do passado" (BACHELARD, 2003:18), mesclando assim a função do real com a função do irreal. A função do real, sendo orientada pelo passado e a função do irreal, inquietando o "ser adormecido nos seus automatismos" se unem através da imaginação para a confecção da obra de arte. 
Para finalizar dialogarei mais uma vez, dentre as inúmeras que virão, com Gaston Bachelard (2003) que escreve : "Reviver o tempo desaparecido é aprender a inquietude de nossa morte. Pensar o tempo é enquadrar a vida". Este trabalho buscou pensar a inscrição destes tempos vividos e narrados que são articulados no plano da memória e da imaginação criadora, buscando "enquadrar a vida" social através dos processos de criação de uma cidade nos enquadres da tela.

\section{REFERÊNCIAS}

BACHELARD, G. A poética do Espaço. São Paulo: Martins Fontes, 2003.

BASTIDE, R. Arte e Sociedade. São Paulo: Companhia Editorial Nacional, 1979.

BOAS, F. L’art Primitive. Paris: Sócieté Nouvelle Adam Biro, 2003.

BOURDIEU, P. As Regras da Arte: gênese e estrutura do campo literário. São Paulo: Companhia das Letras, 1996.

DE CERTEAU, M. A invenção do Cotidiano. Petrópolis: Vozes, 1997.

ECKERT, C.; ROCHA, A. L. C. "A Memória como Espaço Fantástico". Iluminuras: Série do Banco de Imagens e Efeitos Visuais, n. 2. Porto Alegre: BIEV, PPGAS/UFRGS, 2000.

FINNEGAN, R. Oral Traditions and the Verbal Arts. London: Routtedge,1992.

FIRTH, R. Nós, os Tikopias: um estudo sociológico do parentesco na Polinésia primitiva. São Paulo: Ed. da USP, 1998.LEACH, E. R. Repensando a Antropologia. 2. ed. São Paulo: Perspectiva, 2001.

LEVI-STRAUSS, C. Antropologia Estrutural. Rio de Janeiro: Tempo Brasileiro,1975. As Estruturas Elementares do Parentesco. 2. ed. Petrópolis: Vozes, 1982.

MAUSS, M. Noção de Técnica do Corpo. In: Sociologia e Antropologia. São Paulo: Cosac \& Naify, 2003.

SAHLINS, M. Ilhas de Historia. Rio de janeiro: Zahar, 1994. 